\title{
Ten years of re-thinking regions from citizens' perspectives
}

The year 2020 has been challenging due to the different overlapping crises related to the COVID-19 pandemic. It is difficult to celebrate amidst the awareness of the worst global suffering in generations. Nonetheless, we consider ourselves extremely fortunate to commemorate ten years of Regions $\mathcal{E}$ Cohesion. It is not lost on us that our commemoration occurs amidst the above-cited crises. The inaugural issue of Regions $\mathcal{E}$ Cohesion (2011) was entitled "Regiones, régions, regions, everywhere. . . But what about the people?" It noted that regional integration had proliferated throughout the 1990s and early 2000s to the point that some scholarship was suggesting that regions could one day substitute nation-states as prominent actors in global affairs. The opening editorial of this issue noted that successful region-building, at the supranational, transnational, and sub-national level was measured in terms of economic prosperity and political stability. The inaugural issue questioned this approach by studying how well regions respond to the needs of citizens. It asked whether regions serve the needs of their people or whether people serve the needs of regional economies. The coronavirus-related crises have merely emphasized many of the shortcomings of regions and regionalisms that this journal has documented throughout its first decade of existence.

The articles included in Regions \& Cohesion volume 1, issue 1 examined the relationships between people and the regions in which they live in different continents of the world. We were honored that some of the leading scholars in the fields of regional, borderland, and development studies contributed to this inaugural issue. In his introductory article, Michael Keating highlighted two analytical points that reflect the journal's intellectual orientation: (1) "we cannot reduce regions and regionalism to a mere functional logic" (Keating, 2011, p. 5); and (2) "we need something more than governance. We need a reinvigorated vision of government as an authoritative system of policy making whose ultimate test of legitimacy is democratic and inclusive rather than narrowly functional or economic" (Keating, 2011, p. 6).

Significant developments in regional integration have occurred in the ten years since Regions \& Cohesion was first published. Regions have not 
embraced the governance challenge recognized by Keating in 2011. Far from substituting nation-states, many observers contend that (supranational) regions are in crisis. Where regions once represented fora for political cooperation, normative development, and mutual understanding, they now are often attacked by populist politicians for promoting globalization that contributes to increased inequalities. The very regions that previously represented symbols of progress and development have recently been framed as "enemies of the people." At the same time, sub-national regions and city-regions have strengthened their actorness in international affairs. They are considered relevant (often identity-based) spaces for policy making and for responding to the challenges of globalization. These responses can be either proactive and based on openness or rather defensive and based on the protection of regional autonomy. Sub-national regional activism is, in turn, often contested within national political contexts.

Throughout its decade of existence, Regions $\mathcal{E}$ Cohesion has highlighted the aforementioned unresponsiveness of regions to the needs of populations, but it has also brought attention to ways that regions can potentially address transnational problems that affect local communities. The journal underlines difficulties that exist in regional governance but generally in a constructive manner through proactive visions proposed by scholars and practitioners for potential solutions. The journal has published numerous articles on the interactions between regions and human rights, gender equality, immigration, water governance, environmental justice, public health, ethnic rights, and sustainable development. Unfortunately, we cannot highlight so many individual contributions in this introduction, but we are pleased to take this opportunity to thank all of the authors who have contributed to the intellectual discussions raised by the journal since its inception. In addition to scientific analyses, we have received thought-provoking contributions from practitioners, such as Nobel Prize Laureate Leymah Gbowee, Jens Martens, Evangelina Arce, Marja Lehto, Moreno Biagioni, Felipe Adrián Vázquez Gálvez, Anthony Turton, Norry Schneider, Katy Fox, Khuat Thu Hong, among other important reflections in our Leadership Forum. We also thank photographers who published photos and texts for our World Family Portrait exhibit and special issue guest editors for their exceptional work recruiting authors, providing guidance to them, and coordinating communication with the journal. Some of these special issues - such as "A changing of seasons? The Arab Spring revolts and past uprisings" (2012), edited by Gilberto Conde, and "At the margins of the State: Political participation and the emergence of citizenships in Latin America" (2017), edited by Catherine Alès and Claudia Puerta Silva, presented in-depth analysis of specific regional issues that affect local communities. Others, such as the special issue en- 
titled "Policy innovation, regional integration and sustainable democracybuilding: The Millennium Development Goals (MDGs) as challenges and vehicles" (2015), edited by Cristina Blanco Sío-López, and the issues on integrated and coherent sustainable development (2018) and gender coherence for development (2016) examined proposed policy solutions across regions for sustainable development challenges.

Throughout this history, we have also been fortunate to receive support from our editorial boards, our associate editors, editorial managers (Constanza Parra, Jill Eriksson, Emeline Nanga, Antonella Fazio, Ricardo Contreras, Nicolas Casuccio, Julia Ros Cuellar), editorial assistants, a committed group of peer reviewers, and of course, the editorial and production teams at Berghahn Journals. Berghahn's commitment to Regions $\mathcal{E}$ Cohesion has been exceptional, even during the COVID-19 pandemic. We are grateful for this outstanding support. We would also like to highlight the contribution of our colleague and associate editor for production, Dr. Edith Kauffer. Her dedication to Regions \& Cohesion (and seemingly unlimited availability when we need support) has been invaluable. Finally, we express our sincerest gratitude to the members of the Consortium for Comparative Research on Regional Integration and Social CohesionSocial Elevation (RISC-RISE), which the journal represents.

This special issue commemorating Regions $\mathcal{E}$ Cohesion's tenth anniversary continues the tradition described herein. Entitled "Re-thinking regions: A citizen perspective," it has been conceptualized and coordinated by the journal's editors, associate editors, and editorial manager. We thank the contributing authors for accepting the challenge to respond to any of the following provocative questions: What contributed to the perceived decline of regions in global affairs? How can regions recover from this perceived decline? How can supranational, transnational, or sub-national regions respond better to the needs of citizens? How can regions better support the Sustainable Development Goals and the transformative development that they pursue? How can regions promote more sustainable usage of natural resources? What roles can regions play in global affairs in the near- to medium-term future? The articles published here provide a snapshot of the state of regional integration in the world today. These articles also engage the field of regional studies, discuss its strengths and weaknesses, and indicate interesting paths for future scholarship. We thank the authors for these proposed ways forward.

This special issue is also the latest product of the fruitful collaboration between the RISC-RISE Consortium and the United Nations University Institute on Comparative Regional Integration Studies (UNU-CRIS). As part of United Nations University, UNU-CRIS has also embraced a cross-disciplinary approach to the study of regions, focusing on applied 
and policy-relevant research. Regions are thereby understood as both formal and informal overlapping ambits for citizens and their policy makers. The 10th anniversary of Regions $\mathcal{E}$ Cohesion coincides (almost) with the 20th anniversary of UNU-CRIS itself. Several collaborators of UNU-CRIS have published in Regions $\mathcal{E}$ Cohesion in the past, including Ana Amaya, Sonja Nita, Bob Deacon, Stephen Kingah, Stefano degli Uberti, Lorenzo Fioramonti, Nahuel Oddone, and Luk Van Langenhove. A special issue on regional migration governance in Europe and Africa was published in 2013 (Deacon et al., 2013), while a special section on multilevel health diplomacy was published in 2019. All of the contributors to this special issue from UNU-CRIS are affiliated with the institute, and we thank them for their contribution. ${ }^{1}$

The articles presented here reflect the current and future roles of regions and what they could or should mean for citizens. John Agnew, author of the lead article in this special issue was a valued member of Regions $\mathcal{E}$ Cohesion's inaugural editorial board. He introduces the innovative regions-cohesion nexus with focus on how much people and place "prosperity" cannot be readily distinguished but are intimately connected. He notes that the inaugural issue of the journal contended that social cohesion can refer to one or more of the positive effects of realizing ethnic identities, anti-poverty measures, and/or welfare and social rights. What these all have in common is a commitment to how the goals of economic growth and social development can only be met satisfactorily if the self-described needs of people are situated locally and regionally. This article examines the current status of social cohesion within the European Union in the light of a necessary balance between global competitiveness and social cohesion potentially restored as the centerpiece of the supranational union. This is a very timely contribution given the intra-regional conflict that has marked the EU response to COVID-19.

This is followed by two conceptual articles by leading scholars in regional studies. The first, by Anne-Laure Amilhat Szary, analyzes the inclusion of gender in regional studies and the inclusion of regions in gender studies. The article highlights the distinct separation of these fields and convincingly argues that gender and even LGBTQIA+ perspectives need to be brought into the field of regional studies in order to make it more inclusive. We are pleased that this article notes Regions \& Cohesion's commitment to gender and women's issues, and we applaud the author's call for further inclusiveness in this field.

Former UNU-CRIS director Luk Van Langenhove then reflects on a social constructivist conceptual framework for regionalism studies and presents a typology and model of how citizens (as socio-psychological subjects) relate to regions. The model presented distinguishes between 
three perspectives: (1) people as adopters of a regional identity; (2) people as region-builders; and (3) people as users of regional concepts. Thus, Van Langenhove presents an innovative and inspiring framework for new research in this area.

The following articles focus on perspectives for regionalism in various world regions. See Seng Tan examines the prospects for the formation of regional community in Southeast Asia that go beyond the statecentric brand of regionalism that has historically defined the Association of Southeast Asian Nations (ASEAN). The author asks: what constitutes a "people-oriented, people-centered and rules-based" and "caring" community as envisaged by the member countries of ASEAN, and where are they in terms of realizing their goal? Tan explores the conditions and constraints affecting ASEAN's progress in remaking Southeast Asia into a people-focused and caring community in three areas: (1) disaster management, (2) development, and (3) democratization (understood here as human rights).

Sébastien Dubé then focuses on Latin America. He suggests a functionalist logic through which he analyzes the evolution of the organizations created during the Latin American post-liberal regionalism wave. Based on public opinion data, the article claims that there is neither demand nor supply for an eventual fifth wave of regionalism that would replicate the previous models. Nonetheless, considering the failure of national governments in fulfilling basic human needs in the region, the author argues that the deepening of the critical social and economic conditions, especially in the COVID-19 pandemic context, could lead to a fifth wave of regionalism in Latin America.

This is followed by two articles on Africa. Tim Shaw and Abigail Kabandula present their perspectives on the opportunities for African developmental regionalisms in the midst of ambivalent geo-political changes and technological developments. The contribution by Djénéba Traoré illustrates how the West Africa Institute (WAI), a RISC-RISE member institute, has contributed to the Economic Community of West African States (ECOWAS) Post 2020 Vision. This article is important because it illustrates how academics can support and promote citizen-centered approaches to regional integration through policy evaluation, training, and scientific diplomacy.

Turning to Europe, Zane Šime addresses multilevel governance in the Baltic Sea Region and looks at how paradiplomacy and science diplomacy play their roles. Finally, Alina Penkala, Ilse Derluyn, and Ine Lietaert critically analyze the case of Ukraine, where an internal divide reflects the reality of belonging to distinct but overlapping regions, and how cit- 
izens cope with this and what it means for their identity. The case study of Ukraine is relevant and will undoubtedly be inspiring for analyses of other situations where citizens live at the intersection of two or more regions or zones of influence (e.g., Mexico and Turkey).

The two articles in the Leadership Forum also embrace an inclusive, citizen perspective on regionalism. The first, written by eleven authors under the leadership of Claudia Puerta Silva presents the case of the Wayuu, an ethnic group who live across the Colombia-Venezuela border. This article is relevant because it shows how a lack of effective and responsive regional governance has impacted this transnational community. The Wayuu have suffered exclusion due to marginalization by both Venezuela and Colombia and the article highlights the impacts of the COVID-19 pandemic on a community that has suffered what the article describes as a "permanent state of crises." The article is innovative because it was written during the pandemic through collaboration between researchers, activists, local leaders, and members of the Wayuu, all of whom have been recognized as co-authors.

This special issue concludes with a contribution by Zenyram Koff Maganda, who became an environmental activist by arguing that civil society organizations should further include youth voices when discussing sustainability for the future. Because this special issue addresses future perspectives for regional integration, we decided that a youth vision of regionalism is an important component of this debate. For this reason, we are proud to publish an article that explains sustainable regional integration to adults from a youth perspective. It highlights present issues and proposes a vision for the future. This article also reflects new RISC-RISE youth activities that will begin in autumn 2020 .

We are very proud of this special issue not only for the quality of the articles but also for the diversity of the participants in terms of origins, professional backgrounds, cultural and ethnic roots, gender, and age. Even though the contributions presented here are in English, Regions $\mathcal{E}$ Cohesion remains committed to multilingualism, publishing articles in French and Spanish as well. The journal is committed to inclusive debates about regions and region-building that promote new academic perspectives and more cohesive networks between researchers and societies. These exchanges are more precious than ever as the COVID-19 pandemic and related crises test regional cohesion throughout the world. As most countries have closed borders and instituted emergency lockdowns, social distancing, and enforced confinements, sharing ideas and contrasting perspectives from people in different world regions refreshes our daily outlooks. The question that guides Regions $\mathcal{E}$ Cohesion's mission is possibly 
more relevant today than it was in 2011 when the journal was born: What are regions without cohesion?

\author{
Harlan Koff, Carmen Maganda, Philippe De Lombaerde, \\ Edith Kauffer, Julia Ros Cuellar \\ Special Issue Editors
}

\title{
NOTES
}

1. UNU-CRIS also wishes to thank Ms. Zanus Fortes for her editorial assistance.

\section{REFERENCES}

Alès, C., \& Puerta Silva, C. (Eds.). (2017). At the margins of the State: Political participation and the emergence of citizenships in Latin America. Special issue. Regions and Cohesion 7(3), 1-108.

Blanco Sío-López, C. (Ed.). (2015). Policy innovation, regional integration and sustainable democracy-building: The Millennium Development Goals (MDGs) as challenges and vehicles. Special issue. Regions and Cohesion 5(3), 1-139.

Conde, G. (Ed.). (2012). A changing of seasons? The Arab Spring revolts and past uprisings. Special issue. Regions and Cohesion 2(3), 1-181.

Deacon, B., Fioramonti, L., \& Nita, S. (Eds.). (2013). Regions without borders? Regional governance, migration, and social protection in Africa and Europe. Special issue. Regions and Cohesion 3(3), 1-166.

Keating, M. (2011). Regions and regionalism. Regions and Cohesion 1(1), 4-7.

Koff, H., \& Maganda, C. (2011). Regiones, régions, regions, everywhere. . . But what about the people? Why Regions \& Cohesion. Regions and Cohesion 1(1), $1-3$. 